\title{
The efficacy of intense pulsed light and heat energy therapy compared to benzoyl peroxide gel $2.5 \%$ in the treatment of mild and moderate acne vulgaris
}

\author{
Triasari Oktavriana ${ }^{1 *}$, Agnes Sri Siswati ${ }^{2}$, Kristiana Etnawati ${ }^{2}$ \\ 'Department of Dermatology and Venereology, Faculty of Medicine, Universitas Negeri \\ Sebelas Maret/UNS Hospital, Surakarta, ${ }^{2}$ Department of Dermatology and Venereology \\ Faculty of Medicine, Universitas Gadjah Mada/Dr. Sardjito General Hospital, Yogyakarta
}

DOI: http://dx.doi.org/10.19106/JMedSci004704201501

\begin{abstract}
The use of technology-based light therapies such as intense pulsed light and heat energy (IPL) provides an alternative therapy for patients with acne. However, clinical evidence is required to evaluate the efficacy and safety of the IPL. This study aimed to evaluate the efficacy of IPL compared to benzoyl peroxide (BP) as standard therapies in patients with acne vulgaris. The study was conducted with randomized controlled trial parallel design involving patients with mild and moderate acne vulgaris. Acne severity was determined by the method of Combined Acne Severity Classification (CASC). Statistical analysis using repeated measurement analysis of variance was conducted to assess the reduction in lesions and number of $P$. acnes in each group followed by independent $\mathrm{t}$-test to compare of both groups. A p value $<0.05$ was considered significant. Sixty-two patients with mild and moderate acne vulgaris were enrolled in this study and treated with IPL (32 patients) and with BP gel 2.5\% (30 patients). Two patients from the IPL were dropped out. All subjects showed improvement in acne lesions. Reduction of the number of non-inflammatory lesions at IPL therapy group was not significantly different than the BP gel $2.5 \%$ at week $2(p=0.705)$ and $4(p=0.186)$. Reduction in the number of inflammatory lesions in the IPL treatment group was not significantly different than BP gel $2.5 \%$ at week $2(p=0.604)$ but significantly higher at week $4(p=0.003)$. The reduction of $P$. acnes colonization in the IPL group was significantly higher than BP gel $2.5 \%$ group at week $2(p=0.000)$ and $4(p=0.000)$. In conclusion, the efficacy of IPL in the reduction of the number of inflammatory lesions and the $P$. acnes colonization is better than BP on patients with acne vulgaris.
\end{abstract}

\section{ABSTRAK}

Penggunaan terapi berbasis teknologi sinar seperti intense pulsed light (IPL) dan energy panas memberikan alternative pada pasien akne. Namun demikian, diperlukan penelitian untuk mengkaji efikasi dan keamanan IPL dibandingkan dengan pengobatan standard dengan BP pada pasien acne vulgaris. Penelitian ini dilakukan dengan desain uji klinis teracak parallel terhadap pasien akne vulgaris derajat ringan dan sedang. Derajat akne diukur berdasarkan metoda Combined Acne Severity Classification (CASC). Analisis statistic dilakukan dengan

$\overline{\text { Corresponding author: triasari@gmail.com }}$ 
analisis variansi pengukuran berulang digunakan untuk menilai penurunan jumlah lesi dan jumlah $P$. acnes pada tiap kelompok dilanjutkan dengan uji-t untuk membandingkan kedua kelompok. Nilai $\mathrm{p}<0,05$ digunakan untuk menyatakan perbedaan secara berrmakna. Enam puluh dua pasien subyek dengan tipe kulit IV dan $\mathrm{V}$ diikutkan dalam penelitian ini dan 32 pasien mendapatkan terapi IPL dan 30 pasien mendapat gel BP 2,5\%. Dua pasien kelompok IPK keluar dari penelitian karena efek samping. Hasil penelitian menunjukkan semua subyek mengalami perbaikan lesi akne. Penurunan jumlah lesi non-inflamasi pada kelompok IPL tidak berbeda bermakna dengan delompok BP 2,5\% pada minggu ke 2 $(p=0,705)$ dan ke $4(p=0,186)$. Jumlah lesi inflamasi kelompok IPL tidak berbeda pada minggu ke $2(p=0.604)$ tetapi lebih baik pada minggu ke 4 dibandingkan kelompok BP $(p=0,003)$. Penurunan jumlah koloni $P$. acnes menunjukkan perbaikan nyata pada kelompok IPL dibanding kelompok BP baik pada minggu ke $2(p=0,00)$ maupun minggu ke $4(p=0,00)$. Disimpulkan, efikai IPL dalam menurunkan jumlah lesi inflamasi dan koloni $P$. acnes lebih baik dibandingkkan BP pada pasien dengan acne vulgaris.

Keywords: acne vulgaris - P. acnes - blackhead -intense pulsed light and heat energy - benzoyl peroxide -

\section{INTRODUCTION}

Acne vulgaris is a common skin disease that affects almost all teenagers and adult population. ${ }^{1,2}$ In outpatients clinic of the Division of Cosmetic, Department of Dermatology and Venereology Dr. Sardjito General Hospital Yogyakarta, acne vulgaris is one of the three major diseases that are often found with a prevalence of approximately $71 \%$ of total visits during the period of 2006-2011. The prevalence of acne vulgaris in Hong Kong amounted to $91.3 \%$, with ages ranging from $15-25$ years and $26.6 \%$ of respondents suffered from psychological disorders. ${ }^{3}$ Psychological effects caused by acne induce the loss of self-esteem and depression which affect their quality of life., ${ }^{4,5}$ The negative effects of acne need to be anticipated by providing education, as well as the effective and efficient acne treatment. ${ }^{6}$

Various modalities for acne therapy are available. ${ }^{7}$ The involvement of various factors related to the pathogenesis of acne vulgaris leads to the emergence of variety of acne therapy modalities. ${ }^{8-10}$ Factors involved include follicular epidermal hyperproliferation, increased production of excessive sebum, Propioni bacterium acnes hypercolonization and inflammatory. ${ }^{11}$ Moreover, it is also needed to consider other factors, such as the duration of disease, response to prior therapy, predisposing to post-inflammatory scars and hyperpigmentation. Patients preference and cost of acne treatment regimens should also be considered to treat acne. . In addition, the late onset of therapeutic action often leads to patients' non-compliance in running acne therapy. ${ }^{12,13}$ Another problem is the resistance of P.acnes due to long-term use of antibiotics that may cause refractory to therapy and the increasing rate of disease recurrency. ${ }^{13,14}$

Benzoylperoxide (BP) is one of the standard therapy of mild and moderate acne that is widely used with a concentration of $2.5 \%$ to $10 \%$ with the goal of reducing $P$. acnes. ${ }^{15}$ Therapeutic effectiveness is equivalent between BP gel 2.5\%, 5\% and 10\%. The irritation effect may be lower by using the concentration of BP gel 2.5\%. ${ }^{16}$ Moreover, benzoyl peroxide can also reduce the potential of $P$. acnes resistance to antibiotic. ${ }^{17-19}$ 
Utilization-based light therapy technology either as mono therapy or in combination with standard therapy provides an alternative treatment option for acne patients. ${ }^{13,20}$ Light therapy target is $P$. acnes or damage to the pilosebasea unit. ${ }^{21}$ Intense pulsed light technology (IPL) as a light-based therapy was developed as an alternative therapy for acne because of its efficacy in accelerating the photochemical reaction of porphyrin, faster onset of action and ability to reduce the risk of bacteria resistance. ${ }^{22}$ IPL technology was developed and combined with thermal energy, known as pulsed intense light and heat energy based on thermal shock mechanism. ${ }^{11}$

Research on the effectiveness of the IPL treatment for acne vulgaris has been conducted in many countries with various results. ${ }^{7}$ Based on the results of systematic review by Hamilton et al. ${ }^{21}$ clinical trials with light therapy has been done with several methods; i.e. comparing with placebo as a control, topical therapy as a control, comparing light therapy with different wavelength, or combined with microdermabrasion as a control. According to identification of the review, they obtained 3 clinical trials on the comparative use of light therapy with topical therapy as a control. The Global Alliance to Improve Outcomes in Acne Group stated that the existing research, in particular light therapy, has varying qualities, but it still rare that light-based therapy is compared with validated pharmacological therapy. ${ }^{23}$ Currently, there is not enough clinical data to support the recommendation of using lightbased systemtherapy ${ }^{24}$, that it still needs more evidence-based research to explain the clinical efficacy and safety of light therapy with different degrees of acne as well as a greater number of subjects and longer follow-up period. ${ }^{25}$ To date, no reported comparative data on the effectiveness of intense pulsed light heat energy therapy with BP gel $2.5 \%$ for mild and moderate acne vulgaris.

\section{MATERIALS AND METHODS}

This study was a randomized controlled trials with parallel design. Subjects were patients with mild and moderate acne vulgaris, had a skin type IV and V. Sample was determined by consecutive sampling. Acne severity was determined by the method of combined acne severity classification (CASC). The study was done in October 2012-January 2013. Patients had provided informed consent and agreed not to change their skin care during this trial. All patients in IPL group were instructed to come to the study twice weekly for 4 weeks and those in BP 2.5\% group were instructed to apply the topical twice daily after washing the facial skin. The condition of acne and side-effects were monitored before and at week 2 and 4 .

The independent variables were the treatment using intense pulsed light and heat energy (IPL) and topical benzoyl peroxide gel $2.5 \%$ (BP 2.5\%). Dependent variable was the result of the effectiveness of such therapy as assessed by a reduction in noninflammatory and inflammatory lesion count number, and decrease number of $P$. acnes. Statistical analysis using repeated measurement analysis of variance to assess the reduction in lesions and $P$. acnes in each group. Comparison of the difference in the mean reduction in lesion and $P$. acnes between the two treatment groups were statistically analyzed by independent t-test with a significance value of $p<0.05$.

The study was approved by the Health Research Ethics Committee of the Faculty of Medicine, Universitas Gadjah Mada, Yogyakarta. 


\section{RESULTS}

A total of 62 patients with mild and moderate acne vulgaris with skin types IV and $\mathrm{V}$ were enrolled in this study and then randomized into two groups. Thirty-two patients included in the test group received the IPL, 30 patients were included in the control group and treated with BP gel 2.5\%. Two patients from the IPL otherwise dropped out due to could not meet the requirements to come routinely to the study. Comparison of characteristics of subjects between two groups is presented in TABLE 1. There was no significant difference between the two groups ( $p>0.05)$.

TABLE 1. Baseline demographic and clinical characteristics of subjects

\begin{tabular}{|c|c|c|c|}
\hline Subjects & $\operatorname{IPL}(n=30)$ & BP $2.5 \%(n=30)$ & $\mathrm{p}$ \\
\hline Age (mean \pm SD) & $21.7 \pm 3.08$ & $21.27 \pm 2.72$ & 0.893 \\
\hline \multicolumn{4}{|l|}{ Sex } \\
\hline - Male & $17(56.7 \%)$ & $19(63.3 \%)$ & 0.598 \\
\hline - Female & $13(43.3 \%)$ & $11(36.7 \%)$ & \\
\hline \multicolumn{4}{|l|}{ Skin type } \\
\hline - Skin type IV & $17(56.7 \%)$ & $14(46.7 \%)$ & 0.438 \\
\hline - Skin type V & $13(43.3 \%)$ & $16(53.3 \%)$ & \\
\hline \multicolumn{4}{|l|}{ Acne severity } \\
\hline - Mild & $15(50 \%)$ & $14(46.7 \%)$ & 0.796 \\
\hline - Moderate & $15(50 \%)$ & $16(53.3 \%)$ & \\
\hline \multicolumn{4}{|l|}{ Count the number of lesions } \\
\hline . Non-inflammatory & $42.01 \pm 13.51$ & $39.80 \pm 14.79$ & 0.622 \\
\hline - Inflammatory & $18.40 \pm 5.17$ & $18.23 \pm 6.90$ & 0.133 \\
\hline P. acnes colonization $($ mean $\pm \mathrm{SD})$ & $1787.23 \pm 481.25$ & $1610.20 \pm 447.06$ & 0.485 \\
\hline
\end{tabular}

In each study group, the mean noninflammatory, inflammatory lesions and the number of $\mathrm{P}$. acnes were significantly decreased. FIGURE 1 shows the significantly decrease in the average number of noninflammatory lesions after 2 weeks and 4 weeks of treatment $(p<0.05)$. The mean percentage reduction in non-inflammatory lesions in the IPL group based on the observations of week 2 and week 4 of treatment were $31.8 \%$ $(\mathrm{p}=0.000)$ and $85.69 \%(\mathrm{p}=0.000)$ respectively, while in BP $2.5 \%$ group, the mean percentage reduction in non-inflammatory lesions according to the observation of week 2 and week 4 of treatment were $30.56 \%(p=0.000)$ and $42.44 \%(p=0.000)$ respectively. 


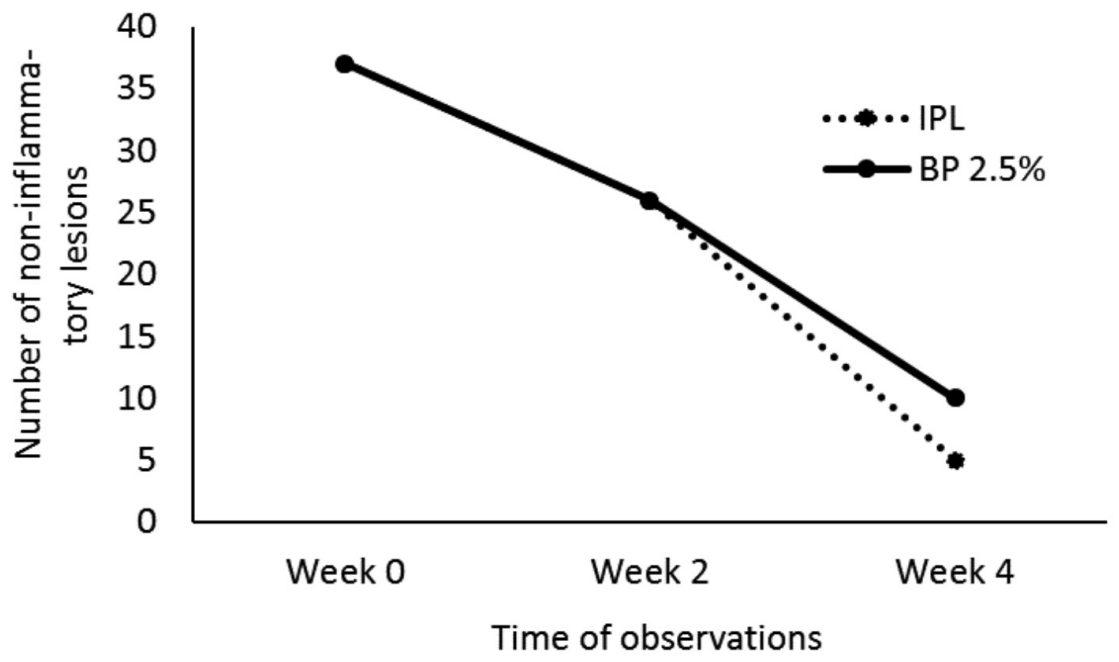

FIGURE 1. Comparison of mean decline in the number of non-inflammatory lesions in both study groups

The mean number of inflammatory lesions in both study groups showed a significantly different $(\mathrm{p}<0.05)$ after 2 weeks and 4 weeks of treatment (FIGURE 2). In the IPL group, the mean percentage reduction in inflammatory lesions based on the observations of week 2 and week 4 compared to week 0 were
$48.47 \% \quad(p=0.000)$ and $85.02 \% \quad(p=0.000)$ respectively. In BP $2.5 \%$ group, the mean percentage reduction in inflammatory lesions based on the observation of week 2 and week 4 compared to week 0 were $41.17 \%(\mathrm{p}=0.000)$ and $69.65 \%(\mathrm{p}=0.000)$ respectively.

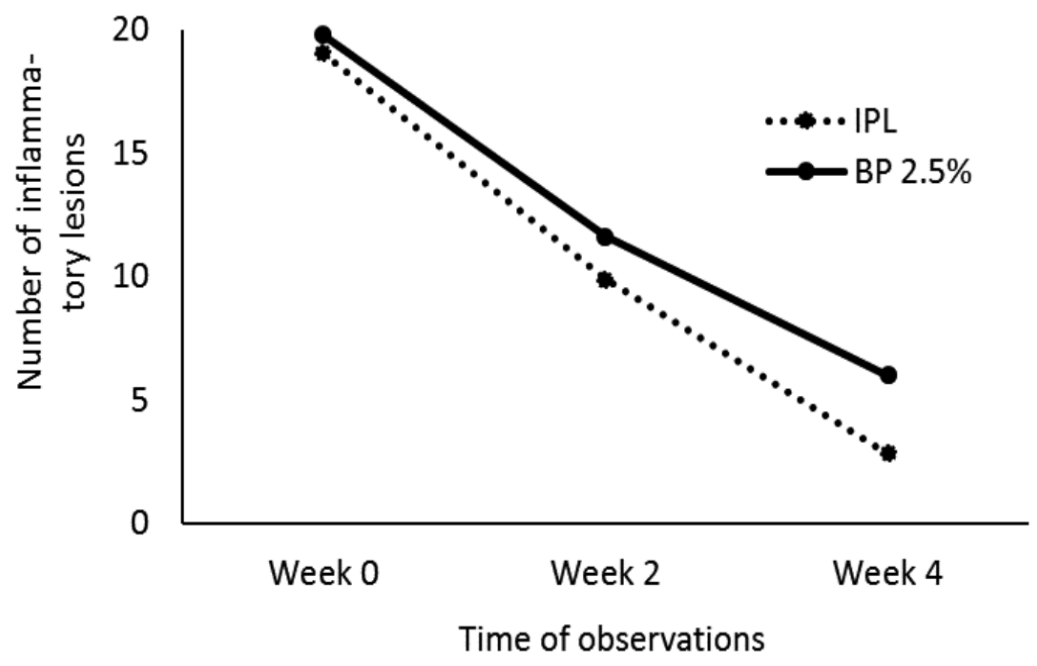

FIGURE 2. Comparison of mean decline in the number of inflammatory lesions in both study groups 
The mean colonization of $\mathrm{P}$. acnes showed reduction in both groups. However, IPL group showed more significant reduction $(p=0.000)$ based on the observation week 0,2 and 4 compared to week 0, as shown in FIGURE 3.

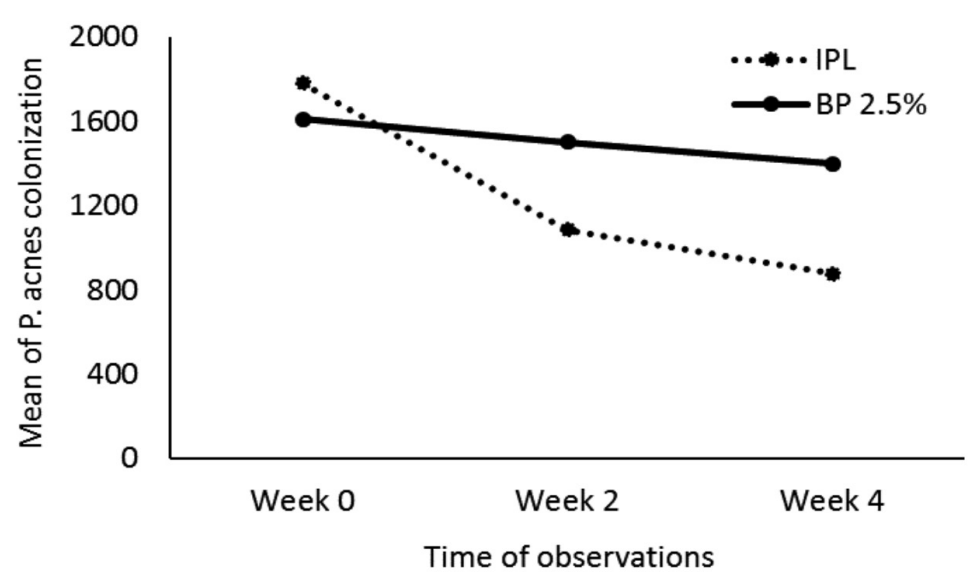

FIGURE 3. Comparison of mean reduction of $\mathrm{P}$. acnes colonization in both study groups

The IPL therapy improved reduction of P. acnes higher than BP $2.5 \%$ group. Mean percentage of $\mathrm{P}$. acnes reduction in IPL group showed $39 \%(\mathrm{p}=0.000)$ after 2 weeks of treatment and $50.78 \%(\mathrm{p}=0.000)$ after 4 weeks of treatment. BP $2.5 \%$ group showed that reduction of $\mathrm{P}$. acnes after 2 weeks and 4 weeks of treatment were $6.8 \%(p=0.000)$ and $13.19 \%(p=0.000)$ respectively.
The treatment efficacy was determined by the percentage of reduction of noninflammatory lesions, inflammatory lesions and the number of P. acnes on the observation of week 2 and week 4 compared to week 0 between the two groups. There was no significantly difference between noninflammatory lesions at week $2(p=0.705)$ and week $4(\mathrm{p}=0.186)$ of treatment in both groups (FIGURE 4).

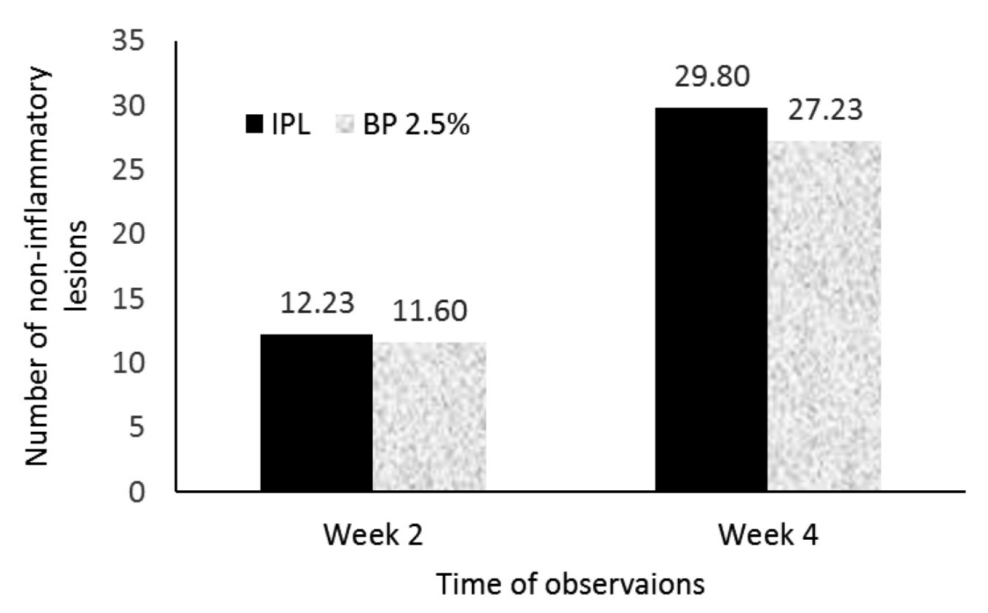

FIGURE 4. Comparison of difference in number of non-inflammatory lesions in both groups 


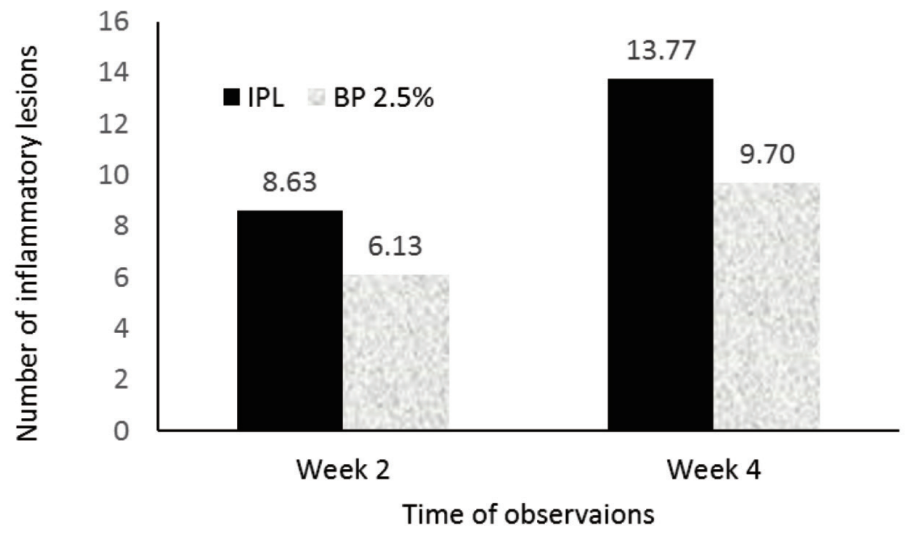

FIGURE 5. Comparison of difference in number of inflammatory lesions in both groups

According to the comparison of mean difference in the number of inflammatory lesions, it was found that the IPL was more effective in reducing inflammatory lesions at week 4 compared to BP $2.5 \% \quad(p=0.003)$.
The effectiveness of these two therapies in inflammatory lesions observation on week 2 was not significantly different $(\mathrm{p}=0.604)$, as shown in FIGURE 5.

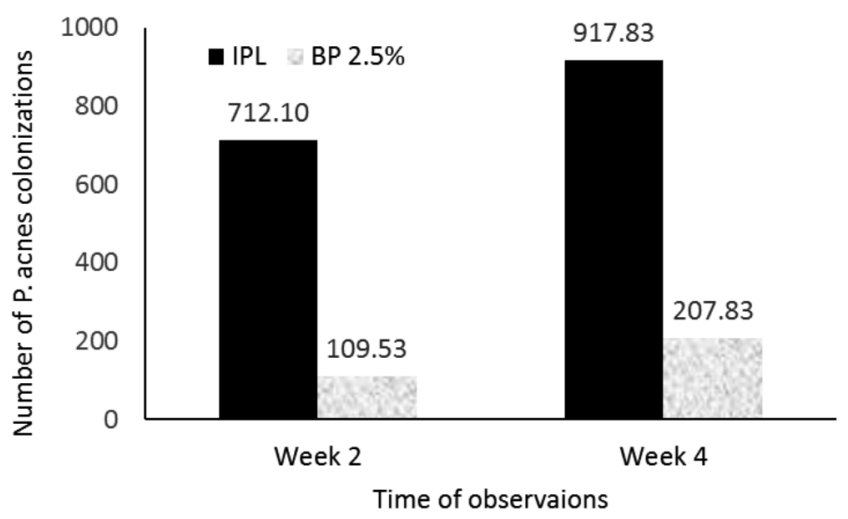

FIGURE 6. Comparison of difference in P. acnes colonization

Based on the treatment efficacy by comparing the mean difference in the number of $P$. acnes on the evaluation of 2 weeks and 4 weeks of treatment, it was found that the IPL was more effective in reducing the colonies of P. acnes compared with BP $2.5 \%$ therapy $(\mathrm{p}=0.000)$, as shown in FIGURE 6 .
Based on the subjects assessment of therapeutic results observed between the two groups at 4 weeks of treatment, no significantly different was found $(\mathrm{p}=0.188)$, as shown in TABLE 2. 
TABLE 2. Subjects assessment of IPL and BP 2.5\% groups at week 4

\begin{tabular}{lcc}
\hline Subjects assessment & IPL $(\mathrm{n}=30)$ & $\mathrm{BP} 2.5 \%(\mathrm{n}=30)$ \\
\hline Getting worse & 0 & 0 \\
No improvement & 0 & 0 \\
Mild improvement & $1(3.33 \%)$ & $3(10 \%)$ \\
Moderate improvement & $3(10 \%)$ & $5(16.67 \%)$ \\
Overall improvement & $26(86.67 \%)$ & $22(73.33 \%)$ \\
\hline
\end{tabular}

All the subjects were monitored for the side effects of therapy. Mild erythema was earned by 2 patients $(6.67 \%)$ in IPL therapy, while dry skin was earned by 4 patients
$(13.3 \%)$ in BP $2.5 \%$ therapy. In the subjects assessment of side effects in both groups, there was no statistically significant difference $(\mathrm{p}=0.334)$ as shown in TABLE 3 .

TABLE 3. Side effects in IPL dan BP $2.5 \%$ groups

\begin{tabular}{lcc}
\hline Side effects & IPL $(\mathrm{n}=30)$ & BP $2.5 \%(\mathrm{n}=30)$ \\
\hline Mild erythema & $2(6.67 \%)$ & 0 \\
Dry skin & 0 & $4(13.33 \%)$ \\
No side effects & $28(93.33 \%)$ & $26(86.67 \%)$ \\
\hline
\end{tabular}

\section{DISCUSSION}

Acne vulgaris is known not only as a follicular infection but also as a chronic inflammatory disease of the pilosebaceous unit. Pathogenesis of acne includes increased sebum production, hypercolonization of $P$. acnes, follicular hyperkeratinization and release of inflammatory mediators. Propionibacterium acnes stimulates T cells, macrophages and keratinocytes to produce inflammatory cytokines through innate and acquired immunity. ${ }^{26}$ By considering factors involved in the pathogenesis of acne, a variety of treatment options has emerged.

This study was conducted to compare the efficacy and safety of two different kinds of therapy, intense pulsed light and heat energy therapy and BP gel $2.5 \%$, during the period of 4 weeks in patients with mild and moderat acne vulgaris. The effectiveness of $\mathrm{BP}^{15}$ and $\mathrm{IPL}^{7}$ therapies in mild and moderate acne has been studied in numerous researches with varying results, but only few studies have compared the two kinds of therapy directly. ${ }^{23}$ In this study, the comparison of treatments of acne with intense pulsed light and heat energy and BP gel 2.5\% demonstrated an effective result for acne treatment on noninflammatory and inflammatory lesions. In this study, the efficacy of the therapy based on the assessment of mean reduction in noninflammatory lesions, inflammatory lesions and colonization of $P$. acnes were assessed at week 0,2 and 4 . Moreover, subjects assessment of treatment outcomes and its side effects were also observed. In the assessment of week 2 and 4, the IPL showed that mean improvement of non-inflammatory lesions decreased by $85.69 \%$ and inflammatory lesions by $85.02 \%$ whereas, in BP $2.5 \%$ group, the mean reduction in noninflammatory lesions and inflammatory lesions were $42.44 \%$ and $69.65 \%$ respectively. The 
resuls of this study was slightly higher than the study by Papageorgiou et al. (2000) with improved non-inflammatory lesions of $75 \%$ and inflammatory lesions of $60 \%$.

Benzoyl peroxide is a potent antimicrobial agent, because of its lipophilic ability that enables BP to penetrate into the pilosebaceous duct and has proven its efficacy in superficial inflammatory lesions. When applied to the skin, BP decomposes in order to release oxygen free radicals, which has a strong bactericidal activity of sebaceous follicles as well as an anti-inflammatory agent. Benzoyl peroxide has an effect on non-inflammatory lesions by reducing follicular hyperkeratosis.,27 Treatment of acne with both IPL and BP has the same target in the pathogenesis of acne, such as $P$. acnes, sebaceous follicles and inflammation. Technology intense pulsed light (IPL) was developed as an alternative therapy for acne because of its efficacy in accelerating the photochemical reaction of porphyrin, faster onset of action and ability to reduce the risk of bacterial resistance. ${ }^{22}$ The IPL technology was developed and combined with thermal energy, known as intense pulsed light and heat energy based on the thermal shock mechanism. ${ }^{11}$ Overall, the provision of therapy in both groups were equally able to reduce colonization of P.acnes, and in this study, IPL therapy was able to reduce the colonization of P.acnes higher $(50.78 \%)$ compared to BP $2.5 \%$ treatment (13.19\%). In this study, the colonization of $P$. acnes was determined by fluorescence follicular redorange that is directly proportional to the levels of sebum, which is in accordance with the study of Dobrev ${ }^{28}$ which states that the porphyrin will appear as a point of red-orange fluorescence in the follicle, which indicates the presence of $P$. acnes bacteria that live in or on the surface of the decline in the number of follicles. The reduction of $P$. acnes accompanied by reduction of porphyrin concentrations will lead to the clinical improvement. Therefore, the determination of porphyrin fluorescence can assist in the evaluation of the degree of acne severity. ${ }^{29}$

The efficacy of therapy was investigated by comparing the mean number of noninflammatory lesions and inflammatory lesions at 2 and 4 weeks of treatment compared with the baseline values. This study demonstrated effective results at 4 weeks of treatment on the inflammatory lesions $(p<0.05)$ and was not effective on non-inflammatory lesions. Hamilton et al. ${ }^{21}$ stated that light-based therapy would provide improved lesion especially in inflammatory lesions such as papules and pustul, while noninflammatory lesions such as comedo and cysts are generally resistant to therapy. This result indicates that decreased colonization of $P$. acnes was higher in IPL compared to BP $2.5 \%$, both on the evaluation of week 2 and week 4 of treatment $(p<0.05)$. This result is suitable with the theory that P.acnes produce porphyrins as part of its normal life cycle. When porphyrins are exposed to visible light or IPL, then the chemistry will be activated, leading to induce a photodynamic reaction that causes destruction of $P$. acnes and sebaceous gland. ${ }^{30}$ Benzoyl peroxide showed its bactericidal activity through oxidation, causing the release of reactive oxygen that will oxidize a high-protein on the cell membrane of bacteria resulting in the destruction of $P$. acnes. ${ }^{31}$ The results of this study indicate that the destruction of $P$. acnes with photodynamic reaction is more effective than oxidation by benzoyl peroxide.

Side effects from the use of benzoyl peroxide may lead to irritation and dryness of skin. ${ }^{30}$ In this study, there were 4 (13.3\%) 
subjects who complained about the dryness of skin. Side effects that occurred in the use of IPL was generally relatively minimal. By modifying the parameter variations in therapy including the outgoing energy, pulse duration and pulse delay, it is possible to minimize the severity of side effects. ${ }^{31}$ Mild erythema was observed on $2(6.67 \%)$ subjects in the IPL group. Otherwise, there was no significant difference in the two groups. Comparison of price therapy for IPL was higher than BP $2.5 \%$. It can be concluded that there was no significant difference between the IPL and the BP $2.5 \%$ groups according to the subjects assessment of therapeutic results $(\mathrm{p}>0.05)$. Overall, all patients of the two groups were satisfied with the results of therapy.

\section{CONCLUSION}

In conclusion, the efficacy of IPL in the reduction of the number of inflammatory lesions and the $P$. acnes colonization is better than BP on patients with acne vulgaris, therefore the IPL can be used as standard therapy of acne vulgaris.

\section{ACKNOWLEDGEMENTS}

We would like to thank all sujects who have participated in this study.

\section{REFERENCES}

1. Dréno F, Poli F. Epidemiology of acne. Dermatol. 2003; 206: 7-10.

2. Strauss JS, Krowchuk DP, Leyden JJ, Lucky AW, Shalita AR, Siegfried EC, et al. Guidelines of care for acne vulgaris management. J Am Acad Dermatol. 2007; 56(4):651-63.

3. Jeong EG, Park HJ, Lee JY. The study of postadolescent acne in nurses. Korean J Dermatol. 2004; 42:1255-63.
4. Thomas DR. Psychosocial effects of acne. J Cutan Med Surg. 2004; 8(4):3-5.

5. Kokandi A. Evaluation of acne quality of life and clinical severity in acne female, adults. Dermatol Res Pract. 2010; 4:1-3.

6. Gupta MA, Gupta AK. Depression and suicidal ideation in dermatology patients, with acne, alopecia areata, atopic dermatitis and psoriasis. Br J Dermatol. 1998; 139: 84650.

7. Savage LJ, Layton AM. Treating acne vulgaris : systemic, local and combination therapy. Expert Rev Clin Pharmacol. 2010; 13(4):563-80.

8. Ross EV. Optical treatments for acne. Dermatol Ther. 2005; 18(3):253-66.

9. Smith EV, Grindlay DJC, Williams HC. What's new in acne? an analysis of systematic reviews published in 2009-2010. Clin Exp Dermatol. 2010; 36:119-123.

10. Rathi KS. Acne vulgaris treatment: the current scenario. Indian J Dermatol. 2011; 56(1):713.

11. Joo Y, Kang H, Choi EH, Nelson JS, Jung B. Characterization of a new acne vulgaris treatment combining light and thermal treatment methods. Skin Res Technol. 2011; 18(1):15-21.

12. Nouri K, Villafradez-Diaz LM. Light/laser therapy in the treatment of acne vulgaris. $\mathrm{J}$ Cosmet Dermatol. 2005; 4(4):318-20.

13. Fernandes NF, Zeichner JA. Laser and lightbased treatments for acne vulgaris. J Cosmet Dermatol. 2010; 23:356-62.

14. Oh SH, Ryu DJ, Han EC, Lee KH, Lee JH. A comparative study of topical 5-aminolevulinic acid incubation times in photodynamic therapy with intense pulsed light for the treatment of inflammatory acne. Dermatol Surg. 2009; 35(12):1918-26.

15. Taylor GA, Shalita AR. Benzoyl peroxidebased combination therapies for acne vulgaris: A comparative review. Am J Clin Dermatol. 2004; 5(4):261-5. 
16. Webster GF. Antimikrobial therapy in acne. In: Webster GF, Rawlings AV. Acne and its therapy. Basic and Clinical Dermatology. New York: Informa Healthcare. 2007; 97102.

17. Warner GT, Plosker GL. Clindamycin/ benzoyl peroxide gel: a review of its use in the management of acne. Am J Clin Dermatol. 2002; 3(5):349-60.

18. Haider A, Shaw JC. Treatment of acne vulgaris. JAMA. 2004; 292(6):726-35.

19. Ramanathan S, Hebert AA. Management of acne vulgaris. J Pediatr Health Care. 2011; 25(5):332-7.

20. Railan D, Alster TS. Laser treatment of acne, psoriasis, leukoderma and scars. Semin Cutan Med Surg. 2008; 27(4):285-91.

21. Hamilton FL, Car J, Lyons C, Car M, Layton A, Majeed A. Laser and other light therapies for the treatment of acne vulgaris: systematic review. Br J Dermatol. 2009; 160(6):1273-85.

22. Rotunda AM, Bhupathy AR, Rohrer TE. The new age of acne therapy: light, lasers, and radiofrequency. J Cosmet Laser Ther. 2004; 6(4):191-200.

23. Shear NH. Newest guidelines for the treatment of acne. Suppl Dermatol Times. 2011; 6-11.

24. Thiboutot D, Gollnick H, Betolli V, Dréno B, Kang S, Leyden JJ, et al. New insight into the management of acne: an update from the global alliance to improve outcomes in acne group. J Am Acad Dermatol. 2009; 60(5):150.

25. Elman M, Lask G. The role of pulsed light and heat energy (LHE) in acne clearance. J Cosmet Laser Ther. 2004; 6(2):91-5.

26. Kim J, Ochoa MT, Krutzik SR, Takeuchi $\mathrm{O}$, Uematsu S, Legaspi AJ, et al. Activation of toll-like receptor 2 in acne triggers inflammatory cytokine responses. J Imunol. 2002; 169(3):1535-41.

27. Bojar RA, Cunliffe WJ, Holland KT. The short-term treatment of acne vulgaris with benzoyl peroxide: effects on the surface and follicular cutaneous microflora. $\mathrm{Br} \mathrm{J}$ Dermatol. 1995; 132(2):204-8.

28. Dobrev H. Fluoresence diagnostic imaging in patients with acne. Photodermatol Photoimunol Photomed. 2010; 26(6):285-9.

29. Borelli C, Merk K, Schaller M, Jacob K, Vogeser M, Weindl G, et al. In vivo porphyrin production by $\mathrm{P}$. acnes inuntreated acne patients and its modulation by acne treatment. Acta Derm Venereol. 2006; 86(4):316-9.

30. Kligman AM. Acne vulgaris: tricks and treatments. Part II: The benzoyl peroxide saga. Cutis. 1995; 56(5):260-1.

31. Ortiz A, Vliet MV, Lask GP, Yamauchi PS. A review of lasers and light sources in the treatment of acne vulgaris. J Cosmet Laser Ther. 2009; 7(2):69-75. 